\title{
Volume of capital services: annual estimates for 1950 to 2008 and new quarterly series
}

Gavin Wallis

HM Treasury

Katy Long

Cambridge Econometrics (formerly Office for National Statistics)

Alex Turvey

HMRC (formerly Office for National Statistics)

\section{Summary}

Capital services are the flow of services into the production of output that are generated by the capital stock, as opposed to the stock of capital itself. As such, capital services are the measure of capital input that is more suitable for analysing and modelling productivity (see Long and Franklin 2010 for new estimates of multi-factor productivity). This article presents experimental capital services estimates for 1950 to 2008. New estimates for 2008 are presented in this article with earlier years updated to incorporate revisions throughout the time series. Revisions are caused primarily by balancing revisions to the constant price plant and machinery series and new data on computer hardware investment. In addition, this article presents for the first time an experimental quarterly series of capital services growth for the whole economy.

\section{Introduction}

In order to enhance the understanding of the UK's productivity performance, a framework is needed to analyse the relationship between the inputs and outputs of production. Accurate measurement of capital and labour inputs, the key factors of production, is essential for the accurate measurement of productivity.

Capital services estimates weight together the growth of the net stock of assets with weights that reflect the relative productivity of the different assets. These weights are calculated using estimates of rental prices. This is in contrast to the capital stock estimates in the UK National Accounts, which use asset purchase prices as weights. This weighting difference is important in understanding the distinction between the two measures of capital. The capital stock estimates in 
the National Accounts are wealth estimates of the capital whereas capital services are a flow measure that reflects the input of capital into production. It is for this reason that capital services are more suitable for analysing and modelling productivity. A capital asset generates a stream of services that spans more than one accounting period. Capital services measure the actual contribution of the capital stock of assets to the production process in a given year.

This article presents new capital services estimates for 2008 along with revised estimates for 1950 to 2007. An accompanying article (see Turvey, Goodridge and Franklin, 2010) presents experimental quality-adjusted labour input (QALI) estimates for the UK for 1997 to 2008 . Together with capital services these form the inputs into the multi-factor productivity (MFP) estimates that are published annually by ONS (see Long and Franklin, 2010).

\section{Estimation methodology}

The methodology used to estimate capital services is described in detail in Wallis (2005), Wallis (2009) and in The ONS Productivity Handbook (ONS 2007). Wallis and Turvey (2009) describe some recent changes to the methodology. No changes to the methodology have been made this time. The methodology for estimating a quarterly series is described in a later section.

The four main stages in the estimation of capital services can be summarised as:

- using the Perpetual Inventory Method (PIM) to calculate a net stock series from a history of constant price investment series

- pricing the services from each asset using an estimated rental for each asset

- generating weights, using the estimated rentals and net stock series, which reflect the input of each asset into production; and

- combining the net stock growth using the estimated weights to give capital services growth estimates

\section{Data}

The data used to estimate capital services are the same as those underpinning the UK National Accounts capital stock estimates and are consistent with Blue Book 2009. The data set consists of a long time series of annual constant price investment flows, classified by industry, their respective life length means (used to calculate depreciation rates) and price deflators.

The asset breakdown of the available investment series in the National Accounts is:

- buildings (excluding dwellings)

- copyright and license costs

- mineral exploration

- own-account software

- plant and machinery including computer hardware and purchased software 
- vehicles

For estimating capital services it is important that both computer hardware and purchased software are given specific treatment as separate assets. This is because their prices relative to other assets have fallen rapidly over time and their economic lives tend to be much shorter than other types of plant and machinery.

In order to treat computer hardware and purchased software as separate assets, they have to be separated from investment in plant and machinery and the associated price deflators have to be adjusted to account for this. It should be noted that, although an appropriate life length is used for computer hardware in the National Accounts (currently assumed to be five years), the capital stock estimates for plant and machinery do not separately deflate computer hardware.

Purchased software is currently treated as part of plant and machinery in the National Accounts; it is not separately deflated and is subject to the general life length for all plant and machinery. However, a series for investment in purchased software is available internally at the ONS and is an updated version of the series published in Chamberlin, Clayton and Farooqui (2007).

\section{Capital services estimates}

This section presents capital services estimates for the whole economy, for the market sector, for the non-oil sector, by eight asset types and by a 57 industry breakdown, consistent with the most recent industry breakdown of gross fixed capital formation in the supply-use tables.

For most asset classes, estimates are available for the period 1950 to 2008 . The full set of data cannot be presented in this article, but is available at www.statistics.gov.uk/statbase/product.asp?vlnk=14205

Figure 1 shows annual growth in capital services for the whole economy. A large degree of cyclicality is exhibited with periods of modest growth coinciding with UK recessions (1973 to 1975, 1979 to 1982, the early 1990s). It should be noted that these estimates only pick-up the start of the recession that started in 2008, and do not reflect the large fall in business investment seen in the UK in 2009. In 2008, capital services grew by 3.2 per cent, down from a revised figure of 4.2 per cent in 2007. This represents a strong slowdown in growth but growth of 3.2 per cent is not weak by historical standards, being around the average growth rate over 1950 to 2008 (3.3 per cent). Although total fixed investment (excluding dwellings) fell by around 1.5 per cent in 2008 , growth of capital services remained positive. This is because despite investment falling it remained above the level of depreciation meaning that net capital stock still grew in 2008.

Figure 1 also shows annual growth in the capital stock, net of depreciation, as published in the UK National Accounts. The series is the growth in total net stock excluding dwellings, since dwellings are not modelled as part of the productive capital stock. Although measuring different concepts, the close fit of the two series is not surprising given they are based on the same underlying data sources. 
The differences in these two series can be attributed to three main factors:

- the weighting of net stock growth by rental prices in the capital services estimates as opposed to weighting by asset prices in the National Accounts estimates

- the separate treatment of computer hardware, purchased software and own-account software for capital services; and,

- the use of a geometric depreciation rate when constructing the capital services estimates instead of an arithmetic depreciation rate

National Accounts net stock is estimated to have grown by 4.1 per cent in 2008 , only slightly slower than growth of 4.2 per cent in 2007 . This highlights how the differences between the two series can be particularly important during periods of recession or strong investment growth.

\section{Figure $1 \quad$ Annual growth in capital services}

Percentages

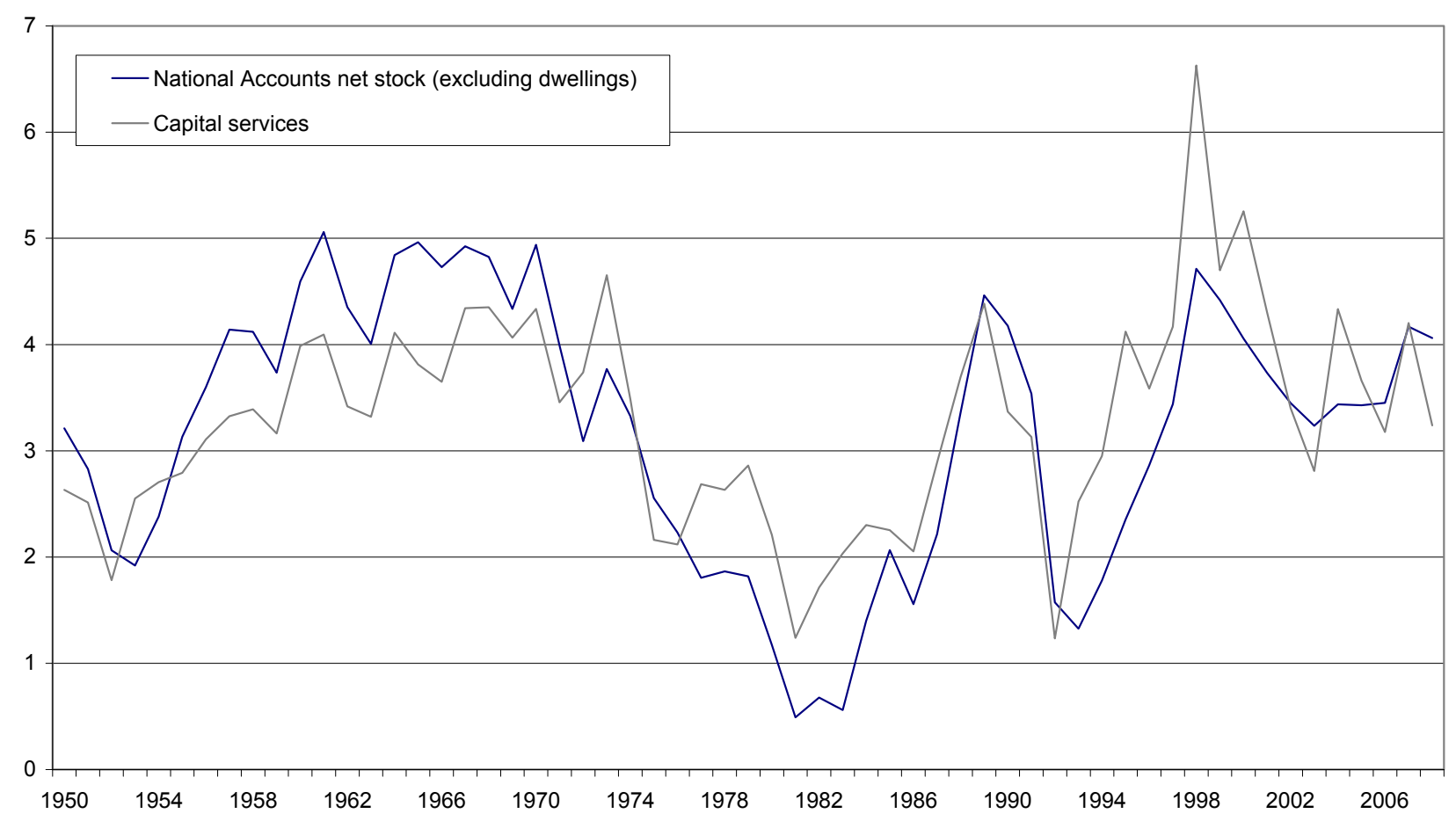

Source: Office for National Statistics

\section{Revisions since previous release}

Revisions to capital services estimates since Wallis and Turvey (2009) arise from revisions to the source data series. The primary source of revisions can be attributed to:

- balancing revisions to the constant price plant and machinery investment series from 2004 onwards

- new data for 2005 onwards, from the supply-use tables, for the proportion of total plant and machinery investment that is computer hardware 
Figure 2 shows the new estimates of whole economy capital services growth against the previously published estimates. The growth in the updated series closely tracks that of the old estimates until 2004 onwards which was the open window for revisions in the 2009 Blue Book. Balancing adjustments to the constant price investment series for plant and machinery post 2003 are the primary driver of revisions to the capital services estimates. (Figure 6 shows revisions to plant and machinery capital services growth.)

The second main source of revisions to whole economy capital services growth comes from the availability of new data from 2005 onwards, from the supply-use tables, for the proportion of total plant and machinery investment that is computer hardware. The effect has been to increase capital services growth in 2005 but reduce it in 2006 and 2007, all else being equal.

\section{Figure 2 Annual growth in capital services: new and previous estimates}

Percentages

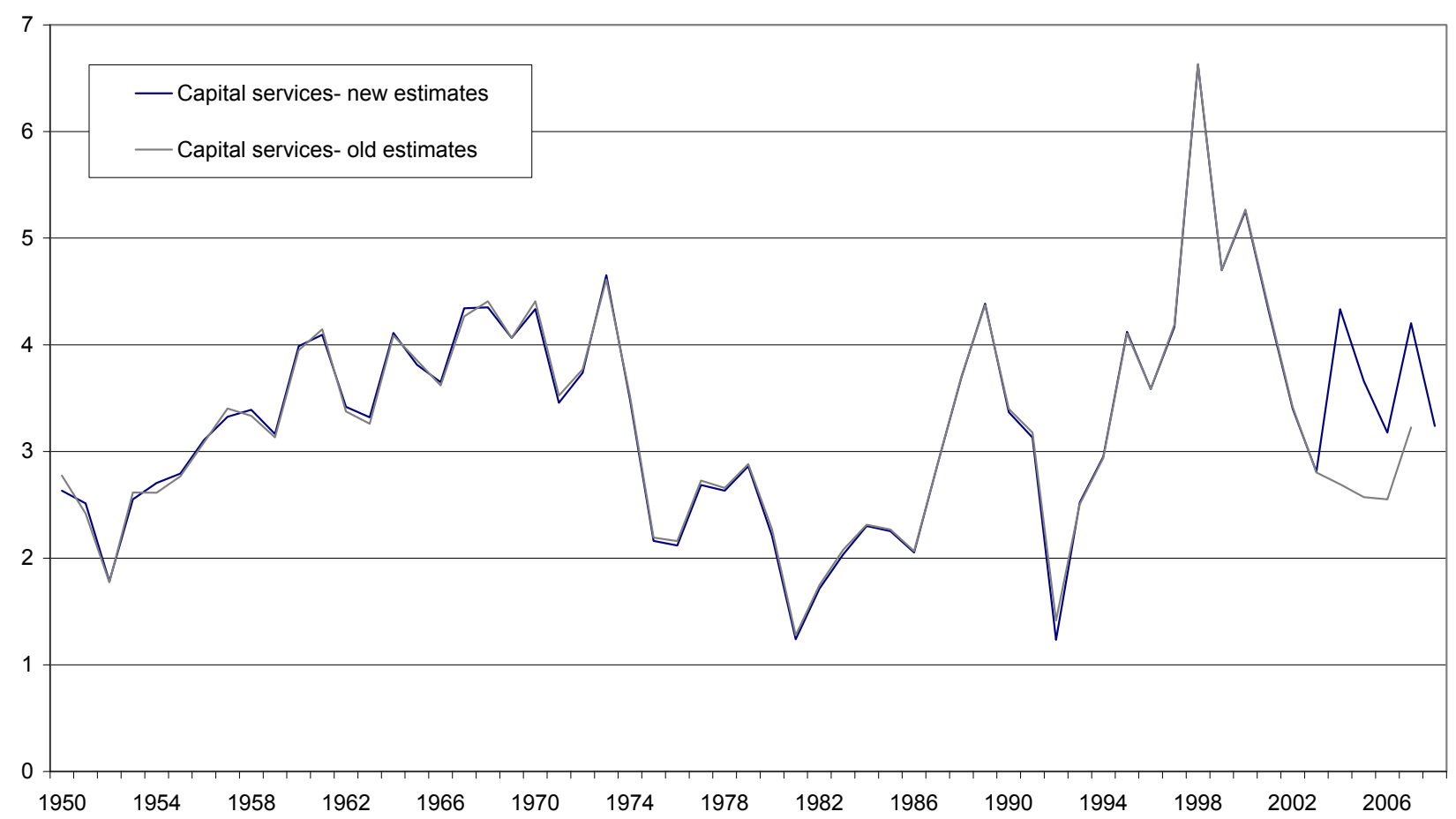

Source: Office for National Statistics

\section{Market sector and non-oil capital services}

Productivity and other macroeconomic analyses often focus on the market sector rather than the whole economy. The measurement of the market sector is of importance to policy makers as the market sector better reflects the balance of demand and supply pressures of the UK economy. The market sector definition is also used in growth accounting analysis, and when estimating and analysing business cycles. In response to user needs, ONS began publishing experimental estimates of market sector productivity in 2007 and market sector capital services were published for the first time in Wallis (2007). 
Macroeconomic analysts are often interested in examining the non-oil sector, as output from the oil sector is considered to have little direct impact on the sustainable level of employment and nonoil economic activity. HM Treasury use measures of non-oil output in analysis of UK trend growth.

Figure 3 plots the annual growth rates in capital services for the market sector, non-oil sector and the whole economy. The market sector here is consistent with the definition of the National Accounts market sector GVA measure, making it suitable for use in market sector growth accounting analysis. Market sector capital services have been growing on average faster than for the whole economy during the period, averaging 3.5 per cent annual growth since 1950 compared with 3.3 per cent for the whole economy. The divergence in the mid-1990s is due to the market sector investing more heavily in ICT assets than the non-market sector. Between 2002 and 2005 annual growth in whole economy capital services exceeded that of the market sector. This coincides with a period of increased government investment in capital projects. In 2008 market sector capital services grew by 3.5 per cent compared to whole economy capital services growth of 3.4 per cent.

\section{Figure 3 Annual growth in whole economy, market sector and non- oil capital services}

\section{Percentages}

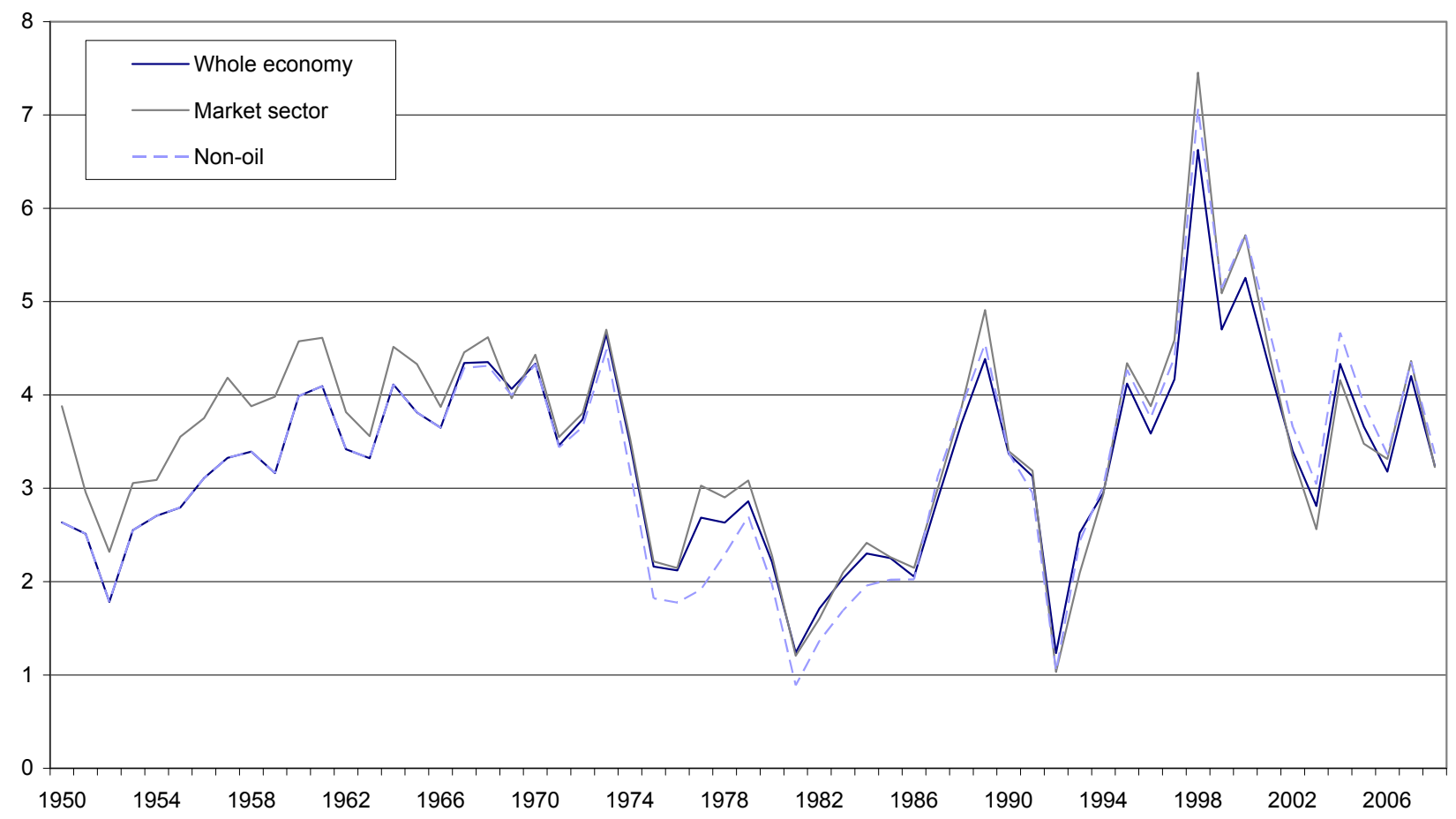

Source: Office for National Statistics

The growth rates of non-oil and whole economy capital services follow each other closely for much of the period, reflecting the small size of assets in the oil and gas extraction industry relative to total UK assets. The divergence in the growth rates between 1975 and 1985 is due to large capital investment in the oil and gas extraction industry as new oil reserves were found in the mid-1970s. These high levels of investment contributed to fast capital services growth in the industry over the 
period. Recently, growth in non-oil capital services has been slightly higher than for whole economy capital services, as oil and gas reserves in the North Sea decline.

\section{Capital services by asset type}

Figure 4 shows annual growth in capital services for buildings (excluding dwellings), plant and machinery (excluding computer hardware and purchased software) and vehicles. Growth in capital services of ICT assets are shown in Figure 5. Some of the more interesting analytical points to note from Figure 4 are:

- growth in capital services from buildings is relatively stable in comparison with the growth in capital services for other asset types

- growth in capital services from vehicles is the most volatile, exhibiting a high degree of procyclicality

- the 1950s and 1960s saw strong and relatively stable growth in capital services for all assets for which data are available

- for all assets there is a downturn in capital services growth from the mid-1970s, driven by a fall in the net stock of capital in many industries over this period

- capital services growth rates were negative for plant and machinery and vehicles during the recession in the early 1990s; and

- capital services from vehicles fell in 2008 while capital services continued to grow from buildings and plant and machinery

Figure 5 shows the volume of capital services from computer hardware, own-account software and purchased software relative to the volume of whole economy capital services, with all series rebased so that 1987 equals 100 . The volume index of computer hardware increases to almost 4,800 in 2008, while the volume index of whole economy capital services (all assets) increases to just over 200 by 2008 . For purchased software, the volume index has increased to over 1,000 in 2008. This is an important factor in explaining the divergence seen in Figure 1 between the wealth-based National Accounts measures of net stock and capital services. The reason that the growth in capital services from computer hardware and purchased software is not driving up whole economy capital services more is that these two assets still only account for about a 10 per cent share of profits (see Table 4). Growth in own-account software capital services is much less pronounced as, although investment in own-account software has increased quite rapidly, the deflator has not fallen as it has for computer hardware and purchased software. The reason for this is that the deflator is based on the average wage index of software-related employees whose wage has increased over the period.

Given that the revisions observed to whole economy capital services growth are very much assetspecific, it is useful to present the revisions to those particular assets which have driven the revisions to the whole economy measure. Figure 6 illustrates the revisions to growth in plant and machinery capital services, excluding computer hardware and purchased software. From 2004 onwards the new estimates of plant and machinery capital services growth exceeds that of the old estimates. This can be attributed to balancing adjustments made to the constant price plant and machinery investment series. 
Figure 4 Annual growth in capital services: by asset type

Percentages

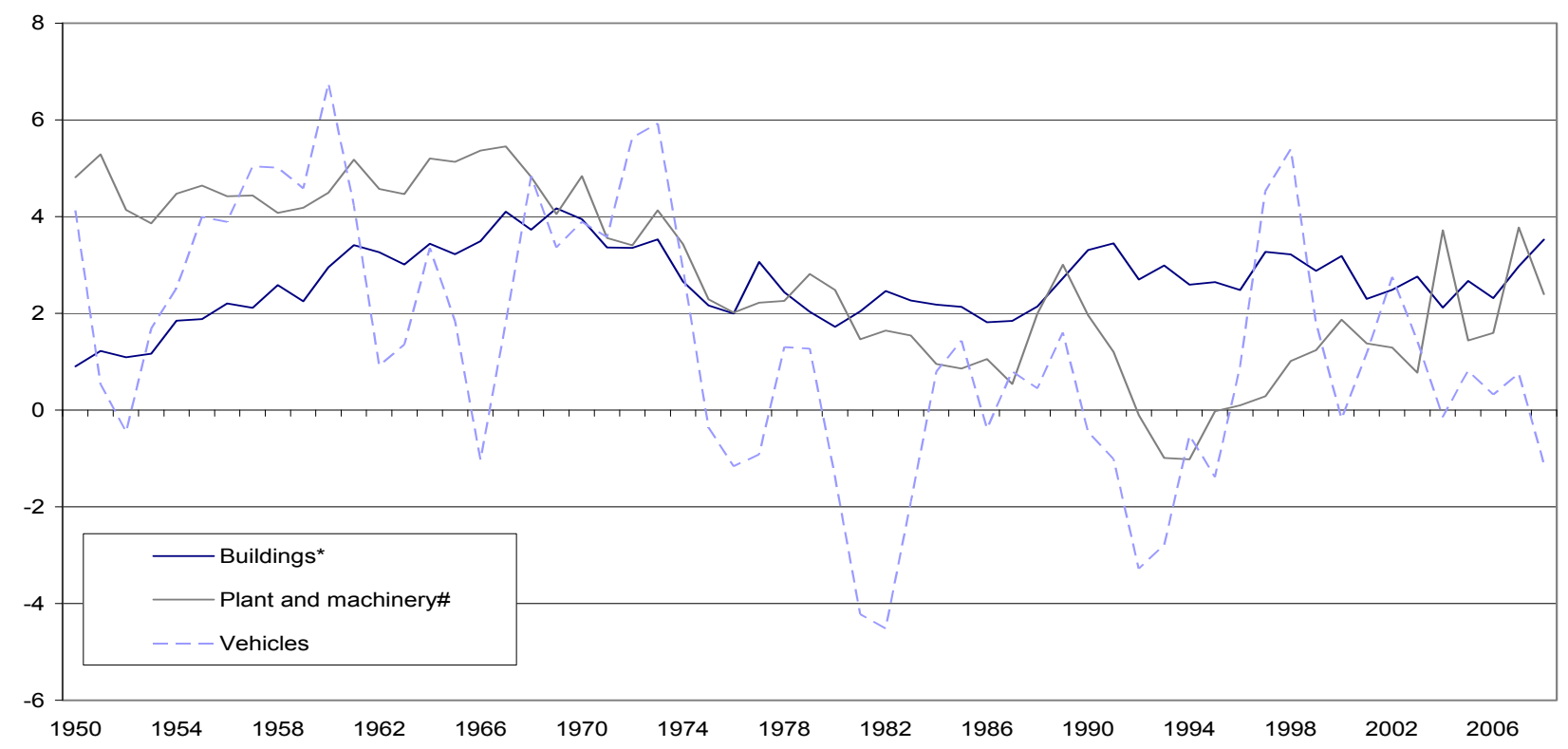

* Excluding dwellings

\# Excluding computer hardware and purchased software

Source: Office for National Statistics

Figure 5 Volume index of whole economy capital services: computer hardware, own-account software and purchased software

Indices

(1987=100

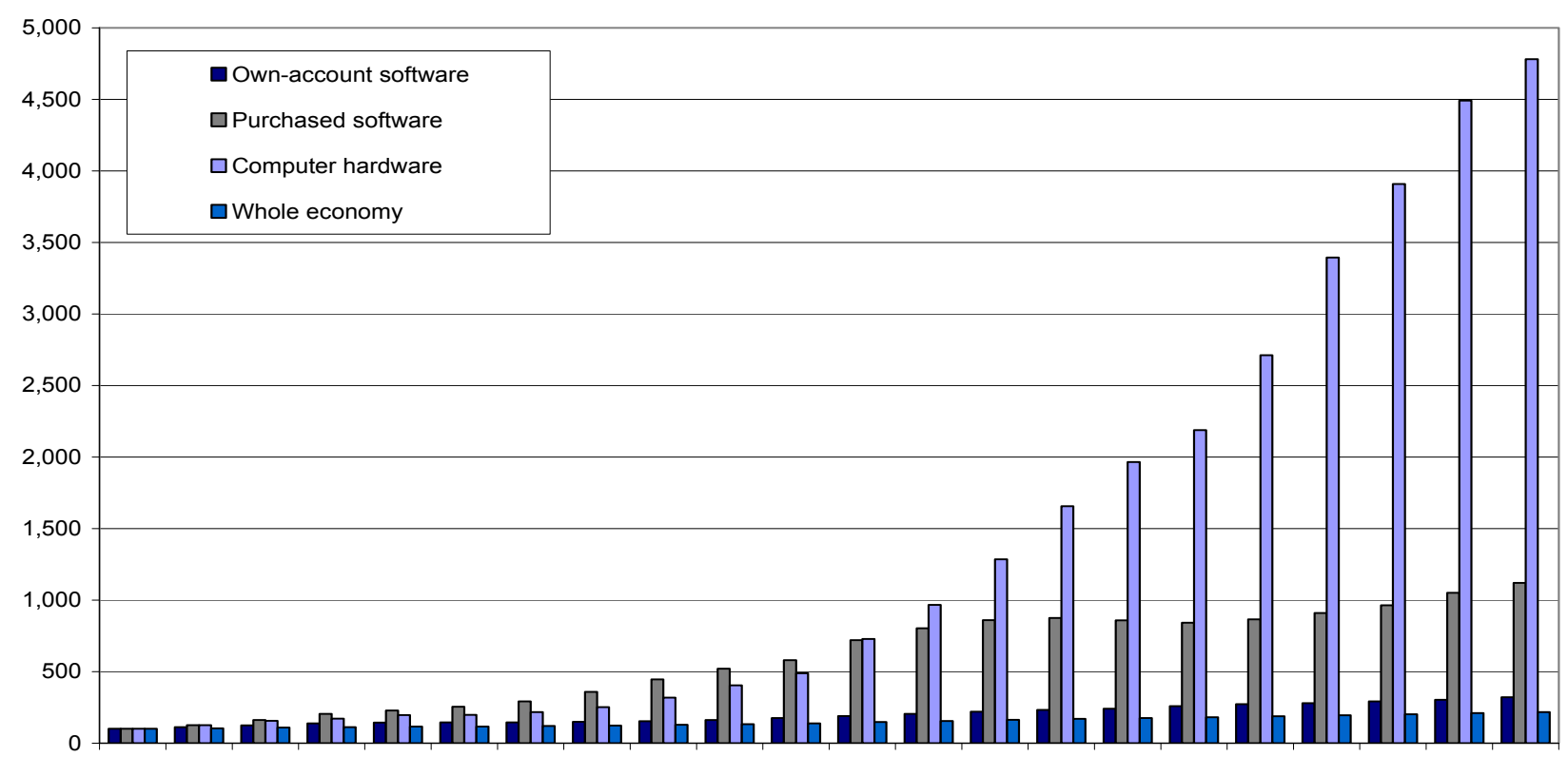

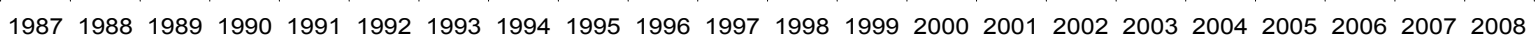

Source: Office for National Statistics 


\section{Figure $6 \quad$ Annual growth in capital services for plant and machinery: new and previous estimates}

Percentages

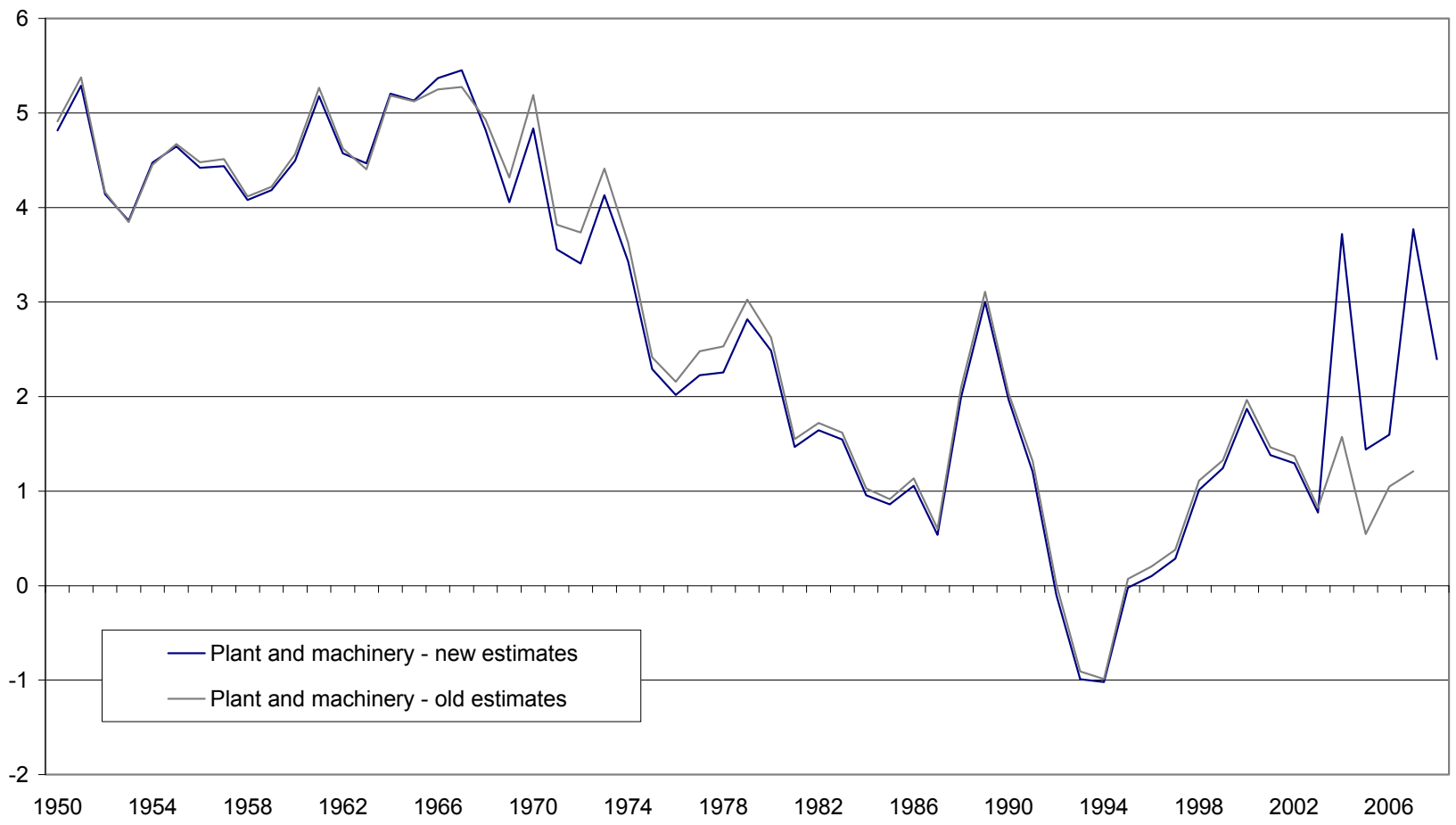

Source: Office for National Statistics

\section{Capital services by industry}

Capital services estimates are produced at a 57-industry level, consistent with the most recent supply-use analysis. Table 1 shows growth in capital services for 2007 and 2008 and for comparison purposes average annual growth for selected periods. The periods chosen are the most recent complete economic cycles. Also included are estimates for aggregate production and aggregate service industries as well as medians and 25th and 75th percentiles. GVA growth for the production and service sectors is shown for comparison.

Interesting points to note from Table 1 are:

- growth in capital services in many production industries was sharply negative in 2007 and 2008, continuing the trend over the last complete economic cycle. Prominent examples include Office machinery \& computers, Radio, TV \& communication equipment, and Other manufacturing

- capital services growth has generally been more robust in 2007 and 2008 across the service sector, although growth has slowed sharply in Wholesale distribution and Computer services; and

- in a small number of industries, including Other transport equipment, Electricity \& gas, Financial intermediation and Education, capital services grew more rapidly in 2007 and 2008 than over the last complete economic cycle 


\section{Table 1 Average annual growth rates in capital services: by industry}

Percentages

\begin{tabular}{|c|c|c|c|c|c|c|}
\hline & $1972-1978$ & 1978-1986 & $1986-1997$ & 1997-2006 & 2007 & 2008 \\
\hline Agriculture & 1.6 & 0.3 & 2.0 & -0.8 & 0.3 & 1.1 \\
\hline Forestry & 1.5 & 2.6 & 2.5 & -2.4 & -1.5 & 1.5 \\
\hline Fishing & 3.9 & -6.1 & -6.7 & -6.0 & -5.0 & -5.3 \\
\hline Coal extraction & 2.5 & 3.0 & -4.3 & -4.3 & -2.2 & -2.0 \\
\hline Oil \& gas extraction & 31.4 & 8.0 & 2.0 & -2.6 & 0.5 & 0.1 \\
\hline Other mining \& quarrying & 1.2 & -1.8 & -1.6 & -1.2 & -0.9 & -1.9 \\
\hline Food products \& beverages & 3.8 & 1.7 & 1.7 & 1.0 & 0.1 & -0.4 \\
\hline Tobacco products & 3.2 & 1.2 & 0.4 & -0.9 & -3.3 & -3.8 \\
\hline Textiles & 0.2 & -2.0 & -0.4 & -2.6 & -2.6 & -1.9 \\
\hline Wearing apparel \& fur products & 1.3 & -1.1 & -0.4 & -2.4 & -4.0 & -3.8 \\
\hline Leather goods \& footwear & 22.4 & 23.7 & 6.9 & -3.8 & -4.6 & -3.4 \\
\hline Wood \& wood products & 4.3 & -2.3 & -0.2 & 0.6 & 0.6 & -1.7 \\
\hline Pulp, paper \& paper products & 34.7 & 24.1 & 15.5 & 1.9 & -3.9 & -2.4 \\
\hline Printing \& publishing & 3.5 & 1.8 & 2.5 & 0.9 & -2.8 & -4.1 \\
\hline Coke, refined petroleum \& nuclear fuel & -0.8 & 2.7 & 1.5 & -2.2 & -6.1 & -3.6 \\
\hline Chemicals \& chemical products & 2.3 & 1.4 & 2.8 & 0.9 & 1.7 & 1.0 \\
\hline Rubber \& plastic products & 3.1 & 1.7 & 4.1 & 0.0 & -1.7 & -2.0 \\
\hline Other non-metallic mineral products & 6.2 & 7.0 & 2.2 & 0.9 & 1.6 & 1.0 \\
\hline Basic metals & 2.0 & -3.6 & -1.3 & -2.1 & -2.7 & -2.3 \\
\hline Metal products & 2.1 & -0.4 & 1.8 & 1.4 & 0.1 & 0.9 \\
\hline Machinery \& equipment & 3.1 & 0.1 & 1.4 & -0.9 & -1.8 & -0.4 \\
\hline Office machinery \& computers & 4.8 & 8.0 & 9.3 & -1.1 & -8.6 & -4.5 \\
\hline Electrical machinery & 3.1 & -1.1 & 1.5 & -1.7 & -3.6 & -1.0 \\
\hline Radio, TV \& communication equipment & 30.5 & 24.7 & 10.4 & -3.6 & -5.8 & -5.9 \\
\hline Medical \& precision instruments & 5.0 & 3.0 & 9.6 & 4.6 & -0.8 & -2.4 \\
\hline Motor vehicles & 2.3 & 3.1 & 3.1 & 0.5 & -0.3 & -0.3 \\
\hline Other transport equipment & 0.9 & 1.4 & -0.1 & 4.4 & 8.0 & 9.2 \\
\hline Other manufacturing & 2.9 & 0.5 & 4.5 & 2.7 & -1.8 & -4.4 \\
\hline Recycling & -42.3 & 10.9 & 0.8 & 6.3 & 23.6 & 20.2 \\
\hline Electricity \& gas & -0.4 & 0.3 & -0.4 & -0.4 & 0.8 & 1.2 \\
\hline Water & 0.7 & 0.9 & 8.6 & 7.1 & 6.1 & 6.6 \\
\hline Construction & 2.5 & -0.3 & 2.0 & 7.1 & 5.8 & 2.5 \\
\hline All production & 2.7 & 1.5 & 1.6 & -0.2 & 0.1 & 0.3 \\
\hline 25th percentile & 1.4 & -0.3 & -0.1 & -2.3 & -3.4 & -3.4 \\
\hline 50th percentile & 2.7 & 1.4 & 1.9 & -0.6 & -1.6 & -1.8 \\
\hline
\end{tabular}




\begin{tabular}{|c|c|c|c|c|c|c|}
\hline 75th percentile & 4.0 & 3.0 & 3.4 & 1.1 & 0.5 & 1.0 \\
\hline Production industries GVA & 2.1 & 1.0 & 1.8 & 0.0 & 0.3 & -3.1 \\
\hline Motor vehicle distribution \& repairs, fuel & 16.5 & 19.3 & 7.2 & 11.6 & 6.4 & 3.8 \\
\hline Wholesale distribution & 4.6 & 3.5 & 5.4 & 4.0 & 1.4 & -0.1 \\
\hline Retail distribution & 5.5 & 4.1 & 5.0 & 7.8 & 7.4 & 5.5 \\
\hline Hotels \& restaurants & 4.7 & 4.3 & 5.5 & 8.0 & 7.4 & 6.7 \\
\hline Land transport \& transport via pipelines & 1.0 & 0.0 & 0.4 & 1.5 & 1.4 & 0.8 \\
\hline Water transport & -0.3 & -9.2 & 0.3 & 0.9 & -8.1 & -4.5 \\
\hline Air transport & 1.2 & 1.2 & 4.4 & 10.4 & 3.4 & 6.9 \\
\hline Ancillary transport services & 1.8 & 3.2 & 6.3 & 10.2 & 7.3 & 8.3 \\
\hline Post \& telecommunications & 3.8 & -0.2 & 4.7 & 8.4 & 3.9 & 3.5 \\
\hline Financial intermediation & 6.2 & 6.3 & 7.9 & 4.2 & 8.2 & 5.4 \\
\hline Insurance \& pension funds & 11.1 & 9.2 & 7.6 & 1.9 & 1.2 & 0.1 \\
\hline Auxiliary financial services & 14.5 & 18.0 & 14.5 & 17.4 & 13.0 & 13.7 \\
\hline Real estate activities & 3.6 & 2.7 & 5.8 & 5.7 & 5.9 & 6.4 \\
\hline Renting of machinery etc & 15.6 & 10.9 & 8.1 & 7.9 & 7.6 & -2.0 \\
\hline Computer services & 22.7 & 23.2 & 24.5 & 26.1 & 22.0 & 2.7 \\
\hline Research and development & 12.7 & 15.9 & 18.9 & 8.3 & 10.1 & 4.4 \\
\hline Other business services & 10.5 & 10.3 & 12.8 & 12.3 & 8.4 & 6.0 \\
\hline Public administration \& defence & 2.0 & 2.1 & 2.8 & 2.6 & 2.1 & 2.0 \\
\hline Education & 2.5 & 0.7 & 1.4 & 5.5 & 7.1 & 7.7 \\
\hline Health and social work & 6.3 & 5.1 & 4.7 & 4.6 & 2.5 & 1.2 \\
\hline Sewage \& sanitary services & 6.8 & 4.0 & 1.4 & 5.6 & 3.4 & 3.9 \\
\hline Membership organisations & 23.0 & 18.6 & 4.4 & 8.8 & 0.5 & 3.4 \\
\hline Recreational services & 5.1 & 5.5 & 6.2 & 9.3 & 10.2 & 10.0 \\
\hline Other service activities & 15.1 & 19.2 & 6.3 & 6.8 & 1.6 & -0.8 \\
\hline All services & 3.4 & 2.7 & 4.5 & 6.7 & 6.0 & 4.5 \\
\hline 25th percentile & 3.3 & 2.6 & 4.4 & 4.5 & 2.0 & 1.1 \\
\hline 50th percentile & 5.9 & 4.7 & 5.6 & 7.9 & 6.1 & 3.8 \\
\hline 75th percentile & 13.1 & 12.1 & 7.7 & 9.5 & 7.8 & 6.5 \\
\hline Service industries GVA & 2.1 & 2.3 & 2.8 & 3.8 & 3.5 & 1.4 \\
\hline
\end{tabular}

Source: Office for National Statistics

An alternative industrial breakdown of capital services is presented in Table 2. This breakdown differs from that in Wallis and Turvey (2009) because the industry breakdown of the associated quality adjusted labour series has been expanded (see Turvey, Goodridge and Franklin 2010). The multifactor productivity release (Long and Franklin 2010) is also presented based on this expanded industry breakdown.

Interesting points to note from Table 2 are: 
- the average annual growth rate of capital services for agriculture, hunting and forestry, fishing, mining and quarrying, electricity, gas and water supply has declined over the entire period, turning negative over the last complete business cycle

- manufacturing is the only industry on this breakdown where the growth in capital services has been negative since the last complete cycle

- the average annual growth rate of capital services for hotels and restaurants has nearly doubled over the entire period, from almost 5 per cent in the 1972-1978 economic cycle to 8 per cent for the most recent complete economic cycle; and

- in all periods other than 1978-1986, the average annual growth rate of capital services is higher for the real estate, renting and business activities than any other industrial group

\section{Table $2 \quad$ Average annual growth rates in capital services: by broad industry}

Percentages

\begin{tabular}{|c|c|c|c|c|c|c|}
\hline & $\begin{array}{c}1972- \\
1978\end{array}$ & $\begin{array}{c}1978- \\
1986\end{array}$ & $\begin{array}{c}1986- \\
1997\end{array}$ & $\begin{array}{l}1997- \\
2006\end{array}$ & 2007 & 2008 \\
\hline $\begin{array}{l}\text { Agriculture, Hunting and Forestry, Fishing, Mining and } \\
\text { Quarrying, Electricity, Gas and Water Supply }\end{array}$ & 2.8 & 2.0 & 0.8 & -0.8 & 1.0 & 1.2 \\
\hline Manufacturing & 2.5 & 1.0 & 2.3 & 0.2 & -0.7 & -0.5 \\
\hline Construction & 2.5 & -0.3 & 2.0 & 7.1 & 5.8 & 2.5 \\
\hline $\begin{array}{l}\text { Wholesale and Retail Trade: Repair of Motor Vehicles, } \\
\text { Motorcycles and Personal Household Goods }\end{array}$ & 5.2 & 4.2 & 5.3 & 6.8 & 5.7 & 3.9 \\
\hline Hotels and Restaurants & 4.7 & 4.3 & 5.5 & 8.0 & 7.4 & 6.7 \\
\hline Transport, Storage and Communication & 1.5 & -1.0 & 2.8 & 6.5 & 3.7 & 4.2 \\
\hline Financial Intermediation & 7.2 & 7.3 & 8.3 & 4.9 & 6.4 & 4.8 \\
\hline Real Estate, Renting and Business Activities & 7.8 & 6.9 & 8.8 & 10.8 & 9.9 & 3.9 \\
\hline $\begin{array}{l}\text { Public Administration and Defence: Compulsory Social } \\
\text { Security, Education, Health and Social Work }\end{array}$ & 2.4 & 1.9 & 2.6 & 3.5 & 3.1 & 3.1 \\
\hline $\begin{array}{l}\text { Other Community, Social and Personal Services } \\
\text { Activities, Private Households with Employed Persons, } \\
\text { Extra-Territorial Organisations and Bodies }\end{array}$ & 5.5 & 5.3 & 4.7 & 8.1 & 7.5 & 7.7 \\
\hline
\end{tabular}

Source: Office for National Statistics

\section{Profit shares}

The weight of each asset or industry in calculating whole economy capital services is the share of gross operating surplus attributable to each asset or to each industry. These are usually referred to as profit shares. Profit shares can be volatile from year to year so, except for the last two years available, are shown in Table 3 as average shares over selected periods. 


\section{Table $3 \quad$ Profit shares: by asset, average income}

Percentages

\begin{tabular}{|c|c|c|c|c|c|c|c|c|c|}
\hline & 1950s & 1960s & 1970s & $\begin{array}{c}1972- \\
1978\end{array}$ & $\begin{array}{c}1978- \\
1986\end{array}$ & $\begin{array}{c}1986- \\
1997\end{array}$ & $\begin{array}{c}1997- \\
2006\end{array}$ & 2007 & 2008 \\
\hline Buildings & 53.3 & 45.1 & 35.8 & 42.8 & 42.4 & 44.3 & 34.8 & 46.7 & 50.1 \\
\hline Computer hardware & 0.0 & 0.0 & 0.0 & 0.0 & 1.0 & 6.4 & 8.4 & 7.2 & 6.8 \\
\hline Copyright and licence costs & 0.0 & 0.0 & 0.5 & 0.5 & 0.6 & 0.8 & 1.2 & 1.2 & 1.2 \\
\hline Mineral exploration & 0.1 & 0.3 & 0.8 & 0.8 & 1.2 & 1.3 & 0.6 & 0.3 & 0.3 \\
\hline Plant and machinery & 34.1 & 41.8 & 47.5 & 41.6 & 39.7 & 31.5 & 35.0 & 26.9 & 24.0 \\
\hline Own account software & 0.0 & 0.0 & 0.8 & 0.8 & 1.5 & 3.1 & 5.1 & 5.3 & 5.6 \\
\hline Purchased software & 0.0 & 0.0 & 1.2 & 1.1 & 1.9 & 3.3 & 5.4 & 4.7 & 4.9 \\
\hline Vehicles & 12.4 & 12.8 & 13.5 & 12.4 & 11.6 & 9.3 & 9.5 & 7.8 & 7.0 \\
\hline
\end{tabular}

Source: Office for National Statistics

Table 3 shows that the composition of profit shares has changed substantially since the 1950 s. More recently, the share of buildings has increased from around 35 per cent in the last full economic cycle to 47-50 per cent in 2007 and 2008. By contrast, the profit share of plant and machinery has declined from 35 per cent over the last full economic cycle to around 25 per cent in 2007 and 2008. The profit share of vehicles has also declined in 2007 and 2008 compared with the last full economic cycle.

Of most interest is the rise of the profit share of computer hardware and software combined, which, although still a relatively small proportion compared to buildings and plant and machinery, has risen from zero in the 1960s to 17 per cent in the most recent cycle. The profit share of computer hardware increased rapidly in the 1980s, 1990s and the early part of this century, culminating in an average share of 8 per cent in the latest economic cycle. Likewise, the profit shares for ownaccount and purchased software have steadily increased from the 1970s, both reaching an average of around 5 per cent in the latest economic cycle. In 2007 and 2008 the profit shares of computer hardware and purchased software have fallen slightly compared to the previous economic cycle while the share of own-account software has continued to increase.

Table 4 presents the average profit shares by broad industry for the last four complete economic cycles and for 2007 and 2008.

Interesting points to note from Table 4 are:

- the average profit share of construction has remained relatively stable throughout the period at around 1 to 2 per cent

- the average profit share of manufacturing, although large, has declined over the period from approximately 26 per cent in the 1972-1978 economic cycle to 20 per cent in the most recent complete economic cycle

- the average profit share of real estate, renting and business activities has more than tripled over the period from approximately 4 to 12 per cent 
- the impact of the recession, which started in 2008 , appears to be limited to manufacturing and government related sectors, with the profit share of manufacturing falling by around 1 per cent in 2008 and the share of 'Other Community, Social...' increasing by around 1 per cent

\section{Table $4 \quad$ Profit shares: by broad industry, average share}

Percentages

\begin{tabular}{|c|c|c|c|c|c|c|}
\hline & $\begin{array}{c}1972- \\
1978\end{array}$ & $\begin{array}{c}1978- \\
1986\end{array}$ & $\begin{array}{c}1986- \\
1997\end{array}$ & $\begin{array}{c}1997- \\
2006\end{array}$ & 2007 & 2008 \\
\hline $\begin{array}{l}\text { Agriculture, Hunting and Forestry, Fishing, Mining and } \\
\text { Quarrying, Electricity, Gas and Water Supply }\end{array}$ & 19.6 & 19.5 & 18.1 & 15.2 & 13.1 & 13.2 \\
\hline Manufacturing & 25.8 & 23.7 & 20.4 & 20.3 & 17.2 & 16.1 \\
\hline Construction & 1.9 & 1.8 & 1.3 & 1.5 & 1.7 & 1.7 \\
\hline $\begin{array}{l}\text { Wholesale and Retail Trade: Repair of Motor Vehicles, } \\
\text { Motorcycles and Personal Household Goods }\end{array}$ & 6.9 & 7.0 & 8.0 & 9.2 & 10.0 & 10.4 \\
\hline Hotels and Restaurants & 1.7 & 1.8 & 1.9 & 2.3 & 3.2 & 3.2 \\
\hline Transport, Storage and Communication & 16.8 & 13.6 & 12.1 & 13.9 & 14.7 & 14.7 \\
\hline Financial Intermediation & 3.6 & 4.0 & 5.8 & 5.6 & 5.8 & 5.8 \\
\hline Real Estate, Renting and Business Activities & 3.9 & 5.8 & 8.4 & 12.1 & 13.7 & 13.8 \\
\hline $\begin{array}{l}\text { Public Administration and Defence: Compulsory Social } \\
\text { Security, Education, Health and Social Work }\end{array}$ & 16.8 & 18.5 & 18.9 & 14.0 & 12.2 & 11.9 \\
\hline $\begin{array}{l}\text { Other Community, Social and Personal Services Activities, } \\
\text { Private Households with Employed Persons, Extra-Territorial } \\
\text { Organisations and Bodies }\end{array}$ & 3.1 & 4.3 & 5.1 & 5.9 & 8.3 & 9.2 \\
\hline
\end{tabular}

Source: Office for National Statistics

\section{Quarterly estimates}

As part of continuous developments to capital services estimates and in response to user demands, an experimental quarterly series has been produced for the first time. This series requires further work and users should note the quality constraints of the series when using it for analysis. Users are advised to use the quarter on same quarter a year ago series rather than the quarter on previous quarter series.

A lack of detailed quarterly investment series means that the method adopted for producing the annual estimates cannot be implemented on a quarterly basis. Instead a quarterly series is approximated using the available annual data together with information on the quarterly path of whole economy investment available from table F of the Quarterly National Accounts. The asset specific quarterly investment series available from this release are used to calculate quarterly net stock series. Quarterly capital services growth is then calculated in the standard way, as described in detail in Wallis (2005), Wallis (2009) and in The ONS Productivity Handbook (ONS 2007).

Annual weights are used in this calculation due to being limited to annual rental series. The series 
covers the period 1965 Q1 to 2008 Q4. Further work is planned to further develop these estimates and also to produce a more timely estimate using the latest available quarterly investment series.

Figure 7 shows the quarterly capital services estimates for the whole economy. Both quarter on previous quarter and quarter on same quarter a year ago series are shown. The latter series looks very similar to the annual growth series in Figure 1. This is because the methodology constrains the quarterly growth series to the annual estimates. The quarterly series is more volatile and occasionally displays jumps or falls between Q4 and Q1. This is a result of constraining growth to the annual net stock series.

\section{Figure $7 \quad$ Quarterly growth in whole economy capital services}

Percentages

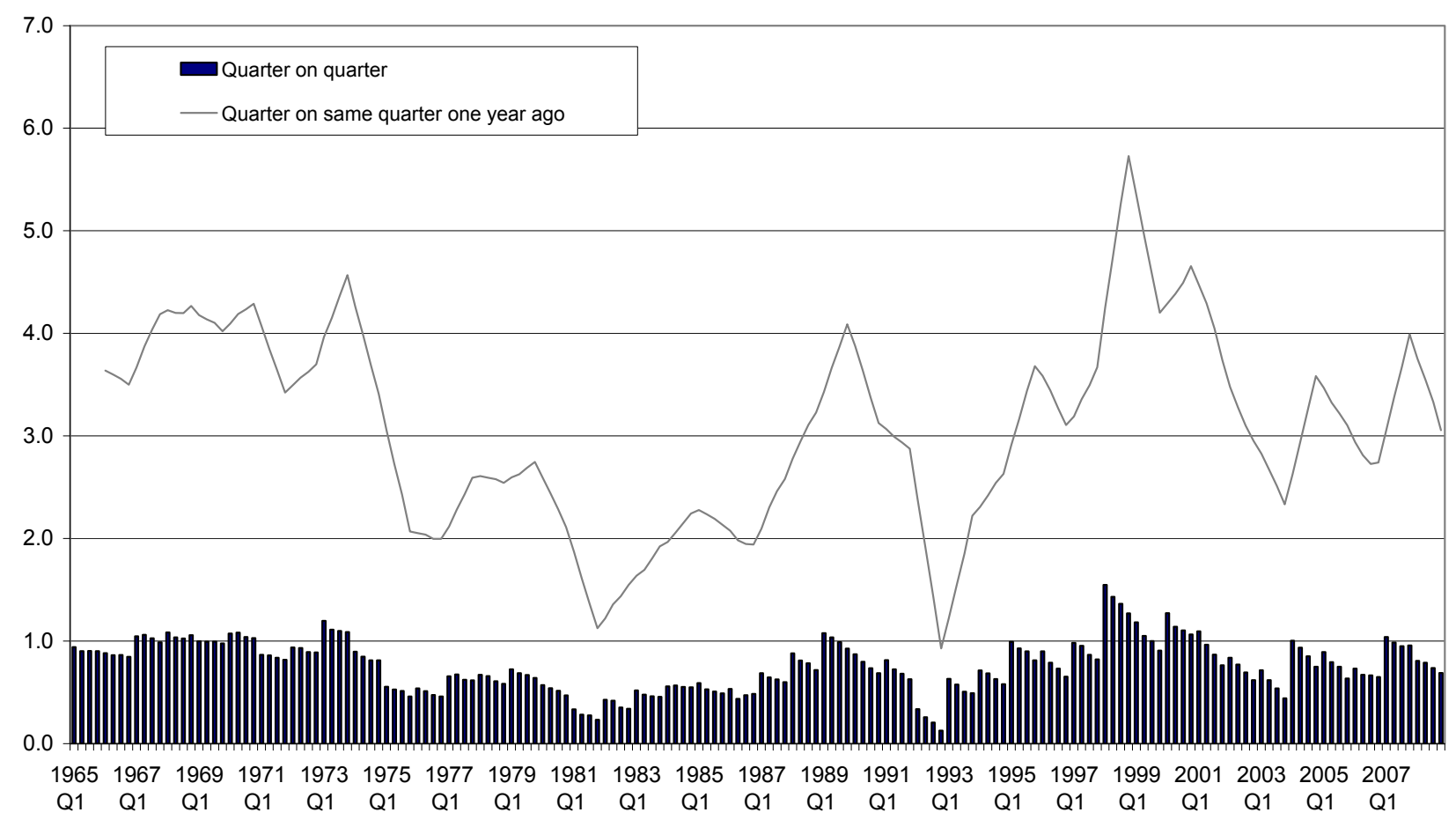

Source: Office for National Statistics

\section{Conclusion}

Capital services are the measure of capital input that is most suitable for analysing and modelling productivity. This article has presented experimental estimates of the capital services growth for the UK as a whole, for the market sector, for the non-oil sector, by eight asset types and by detailed industry. An experimental quarterly series has been produced for the first time. The estimates presented here have been revised since the previous release due to revisions to the source data. However, the main observation continues to be the high growth in capital services from computer hardware and purchased software and much stronger growth in the services industries than in the production industries over recent years. There has also been a clear shift in the profit share from other assets to ICT assets and also from production industries to services industries. 
The impact of the recession, which began in 2008, has yet to appear strongly in the capital services data. Investment fell in 2008 but whole economy capital services still grew by 3.2 per cent. This was a decrease from the revised figure for 2007 and below the average of 4.3 per cent during the most recent complete economic cycle but is comparable to the long-run series average.

\section{Further information}

Links to articles and data for experimental capital services are available at www.statistics.gov.uk/statbase/product.asp?vlnk=14205

Links to articles and data for experimental multi-factor productivity are available at www.statistics.gov.uk/statbase/product.asp?vink=14901

\section{Contact}

elmr@ons.gsi.gov.uk

\section{References}

Chamberlin G, Clayton T and Farooqui S (2007) 'New measures of UK private sector software investment', Economic \& Labour Market Review 1(5), pp 17-28 and at www.statistics.gov.uk/cci/article.asp?id=1798

Hall R E and Jorgenson D W (1967) 'Tax Policy and Investment Behaviour', American Economic Review Vol. 57, No. 3, pp 391-414

HMT (2008) Evidence on the economic cycle, available at www.hmtreasury.gov.uk/d/pbr08_economiccycle_712.pdf

Hulten C R and Wykoff F C (1981a) 'The estimate of economic depreciation using vintage asset prices'. Journal of Econometrics Vol. 57, pp 367-96.

Hulten C R and Wykoff F C (1981b) 'The measurement of economic depreciation', In Hulten C R (Ed), Depreciation, inflation and the taxation of income from capital. The Urban Institute Press.

Jorgenson D W (1963) 'Capital Theory and Investment Behaviour', American Economic Review Vol. 53, No. 2, pp 247-59.

Jorgenson D W and Griliches Z (1967) 'The explanation of productivity change', Review of Economic Studies Vol. 34, No. 3, pp 249-83.

Long K and Franklin M (2010) 'Multi-factor productivity: estimates for 1994 to 2008', Economic \& Labour Market Review 4(9), pp 67-72, available at www.statistics.gov.uk/cci/article.asp?ID=2576 
Office for Economic Co-operation and Development (2001) Measuring Productivity - OECD Manual.

Office for Economic Co-operation and Development (2001b) Measuring Capital - OECD Manual.

Office for National Statistics (2007) The ONS Productivity Handbook: A Statistical Overview and Guide at www.statistics.gov.uk/about/data/guides/productivity/default.asp

Oulton N and Srinivasan S (2003) 'Capital stocks, capital services, and depreciation: an integrated framework', Bank of England Working Paper No. 192 and at www.bankofengland.co.uk/publications/workingpapers/wp192.pdf

Turvey A, Goodridge P and Franklin M (2010) 'Quality-adjusted labour input: estimates for 1993 to 2008' available at www.statistics.gov.uk/cci/article.asp? ID $=2479$

Wallis G (2005) 'Estimates of the volume of capital services', Economic Trends 624, pp 42-51 and at www.statistics.gov.uk/cci/article.asp?id=1297

Wallis G (2007) 'Volume of capital services: estimates for 1950 to 2005', Economic \& Labour Market Review 1(7), pp 39-47 and at www.statistics.gov.uk/cci/article.asp?id=1827

Wallis G and Turvey A (2009) 'Volume of capital services: estimates from 1950 to 2007', Economic \& Labour Market Review 3(1), pp 53-61 and at www.statistics.gov.uk/cci/article.asp?ID=2105

Wallis G (2009) 'Capital Services Growth in the UK: 1950 to 2006', Oxford Bulletin of Economics and Statistics, vol. 71, no. 6, pp. 799- 819. 